\title{
Consistently large marine reservoir ages in the Norwegian Sea during the Last Deglaciation
}

\author{
Svante Björck ${ }^{\mathrm{a}, *}$, Nalân $\mathrm{Koç}^{\mathrm{b}}$, Göran Skog ${ }^{\mathrm{c}}$ \\ ${ }^{a}$ Department of Geology, Quaternary Geology, Lund University, Tornav. 13, SE-223 63 Lund, Sweden \\ ${ }^{\mathrm{b}}$ Norwegian Polar Institute, Polarmilj申senteret, N-9296 Troms $\phi$, Norway \\ ${ }^{\mathrm{c}}$ Department of Geology, Quaternary Geology, Radiocarbon Dating Laboratory, Lund University, Tornav. 13, SE-223 63 Lund, Sweden
}

Received 24 October 2002; accepted 20 December 2002

\begin{abstract}
With the exception of the GS-1/Younger Dryas cold period marine reservoir ages for the Last Deglaciation in the North AtlanticNorwegian Sea are generally assumed to have been around 400-500 radiocarbon years in magnitude (Earth Planet. Sci. Lett. 126 (1994) 275; Radiocarbon 37 (1995) 53; Quat. Res. 52 (1999) 104; Nature 412 (2001) 724). By comparing the climate records obtained from the GRIP ice-core (Nature 359 (1992) 311; J. Quat. Sci. 13(4) (1998) 283) and from North Atlantic/Norwegian Sea cores (Quat. Res. 52 (1999) 104; Geology 23 (12) (1995) 1059; Nature 356 (1991) 757; Nature 356 (1992) 757; Paleoceanography 3(1) (1988) 1; Nature 343 (1990) 612; Earth Planet. Sci. Lett. 126 (1994) 275), with radiocarbon-dated European continental records, we show that marine reservoir ages in the Norwegian Sea were of the order of $1000{ }^{14} \mathrm{C}$ yr, including large uncertainties. This approach rests on the reasonable assumption that climate changes throughout the NE Atlantic and Europe were more or less synchronous at the centennial scale. Fairly large variations in reservoir ages over time may have been caused by changing atmospheric ${ }^{14} \mathrm{C}$ content. The results indicate that detailed land-sea correlations for the North Atlantic during the Last Deglaciation are not feasible using radiocarbon dating alone.
\end{abstract}

(C) 2003 Elsevier Science Ltd. All rights reserved.

\section{Introduction}

Detailed comparisons between marine, ice core and terrestrial records of the Last Deglaciation in the N. Atlantic region, and estimates of the leads and lags between them are hampered by major chronology uncertainties affecting the marine records in particular. Possibly the most important sources of uncertainty are related to temporal and spatial changes in the marine reservoir effect, which remain poorly understood. Nevertheless, precise correlations between various marine proxy records and the Greenland Summit ice cores have frequently been proposed (e.g. Bond et al., 1993; Haflidason et al., 1995).

It has recently been shown, however, that three North Atlantic marine records from sites north of $40^{\circ} \mathrm{N}$ indicate that apparent surface-water ages (the so-called marine reservoir age) at 15,000 cal. yr BP exceed modern

\footnotetext{
*Corresponding author. Tel.: +46-46-222-7882; fax: +46-46-2224830.

E-mail address: svante.bjorck@geol.lu.se (S. Björck).
}

reservoir values by $1200-1900{ }^{14} \mathrm{C}$ yr (Waelbroeck et al., 2001) and by $800-1000{ }^{14} \mathrm{C}$ yr at 12,000 cal. yr BP. Higher reservoir ages during the GS-1/Younger Dryas have also been suggested by earlier studies (Bard et al., 1994; Austin et al., 1995). By contrast, it is generally assumed that the magnitude of the regional marine reservoir age during the intervening warm period, the Bølling-Allerød interval or Greenland interstadial 1 (GI-1), approximated that of modern reservoir ages (Bondevik et al., 1999; Waelbroeck et al., 2001).

\section{Material and methods of correlation}

Radiocarbon dating of time-parallel marker horizons, such as tephra layers that are common to marine and continental sequences, are required to test any temporal and spatial changes in reservoir ages. However, there are few tephra layers within the Last Deglaciation interval, and the marine tephra stratigraphy is particularly problematic (Bond et al., 2001). The only method available, therefore, is to make detailed comparisons 
between paleoceanographic and terrestrial records using the event stratigraphy approach (Björck, et al., 1998; Walker et al., 1999). Regional climatostratigraphic boundaries can be used as more or less synchronous marker events, and thus temporal and spatial variations of reservoir ages can be estimated for the North Atlantic for the period between 15,000 and $11,000 \mathrm{cal}$. yr BP.

\subsection{Synchronous changes}

The notion that climate changes in the North Atlantic region during the Last Deglaciation were more or less synchronous has become widely accepted during the last few years. The deep Greenland ice cores have been adapted as palaeoclimatic templates and, with the aid of tephra stratigraphy (Haflidason et al., 1995) and matching of ${ }^{14} \mathrm{C}$ data-sets (Björck et al., 1996), it has been concluded that Norwegian Sea records, European lake records and tree-ring variations are synchronous with ${ }^{18} \mathrm{O}$ variations in the ice-cores. Furthermore, a common sequence of events during the interval 15,00011,000 cal. yr BP has convincingly been demonstrated for a diversity of proxy records obtained from sites throughout the North Atlantic region (Björck, et al., 1998; Walker et al., 1999), as well as for records obtained from the Caribbean Sea (Hughen et al., 1998) and the Santa Barbara basin (Kennett and Ingram, 1995). If similar North Atlantic marine ${ }^{14} \mathrm{C}$ dated paleoclimatic sequences are found, then it should be possible to estimate the magnitude of regional marine reservoir variations during the Last Deglaciation, where these exceed the uncertainties in the dating and correlation methods employed.

\subsection{Four marine records}

Because of the many uncertainties that affect marine ${ }^{14} \mathrm{C}$ dates, reliable estimates of reservoir ages require robust marine ${ }^{14} \mathrm{C}$ data-sets. Here we present palaeoceanographic records and associated ${ }^{14} \mathrm{C}$ data-sets from four marine cores. Three are located in the Norwegian Sea and one in the North Atlantic, west of Ireland (Fig. 1). A record of August SSTs based on transfer function inferences of diatom assemblage data has been obtained from core HM79-6/4 (Koç Karpuz and Jansen, 1992; water depth $=983 \mathrm{~m}$ ), while records of the polar planktonic foraminifera Neogloboquadrina pachyderma (s.) have been obtained from cores Troll 8903 (Haflidason et al., 1995, water depth $=300 \mathrm{~m}$ ), Troll 3.1 (Lehman et al., 1991; Lehman and Keigwin, 1992, water depth $=322 \mathrm{~m}$ ), and V23-81 (Broecker et al., 1988; Jansen and Veum, 1990; Bard et al., 1994, water depth $=2393 \mathrm{~m}$ ). These four records match well the pattern of ${ }^{18} \mathrm{O}$ variations in the GRIP ice-core record (Fig. 2). Since it is highly unlikely that North Atlantic and Norwegian Sea surface temperatures were in anti-

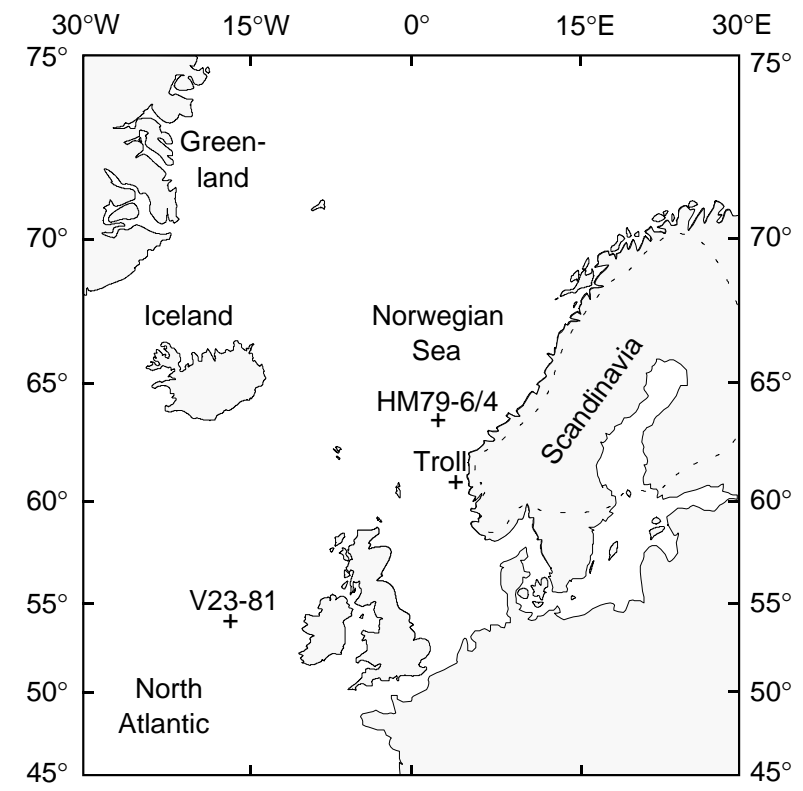

Fig. 1. Map showing the region between NW Europe and Greenland, including the location of the four marine cores, where Troll is the location of two. The dotted line over Scandinavia shows the extent of the Fennoscandian ice-sheet at the Younger Dryas/Preboreal transition at 11,500 cal. yr BP.

phase with air temperature variations in Greenland and in western and central Europe during the Last Deglaciation, any time lags between the ice-core and marine records must be shorter than the duration of the shortlived climate events identified in the records, i.e. $<150$ ice $\mathrm{yr}$. This is also within the 1-sigma dating errors of most of the marine ${ }^{14} \mathrm{C}$ dates used here. Furthermore, the onset of major warming in Greenland at the GS-2/ GI-1 transition (14,700 ice yr BP) may have been slightly lagged compared with warming of the near-by ocean and continents, but a significant time-lag between the Norwegian Sea/North Atlantic records and those of northwest Europe is highly unlikely. With the exception of the V23-81 core, the marine cores discussed here have high sedimentation rates, and are thus suitable for detailed correlations with the high-resolution ice-core records. Reasonably detailed series of ${ }^{14} \mathrm{C}$ dates are available for all 4 records (Table 1), while the well-dated Vedde Ash has been found in three of them (Fig. 2).

\subsection{Dating uncertainties}

For a direct comparison of marine ${ }^{14} \mathrm{C}$ chronologies with reliable terrestrial ones, using the GRIP event stratigraphy scheme as a template, the ${ }^{14} \mathrm{C}$ chronology of the GRIP event horizons needs to be established. For this purpose we have evaluated well-dated terrestrial sequences, which show at least some of the key events of the GRIP record. We have tried to use at least two different ${ }^{14} \mathrm{C}$ dated data-sets for each defined event boundary (Table 1). Because of fluctuations in 
HM79-6/4

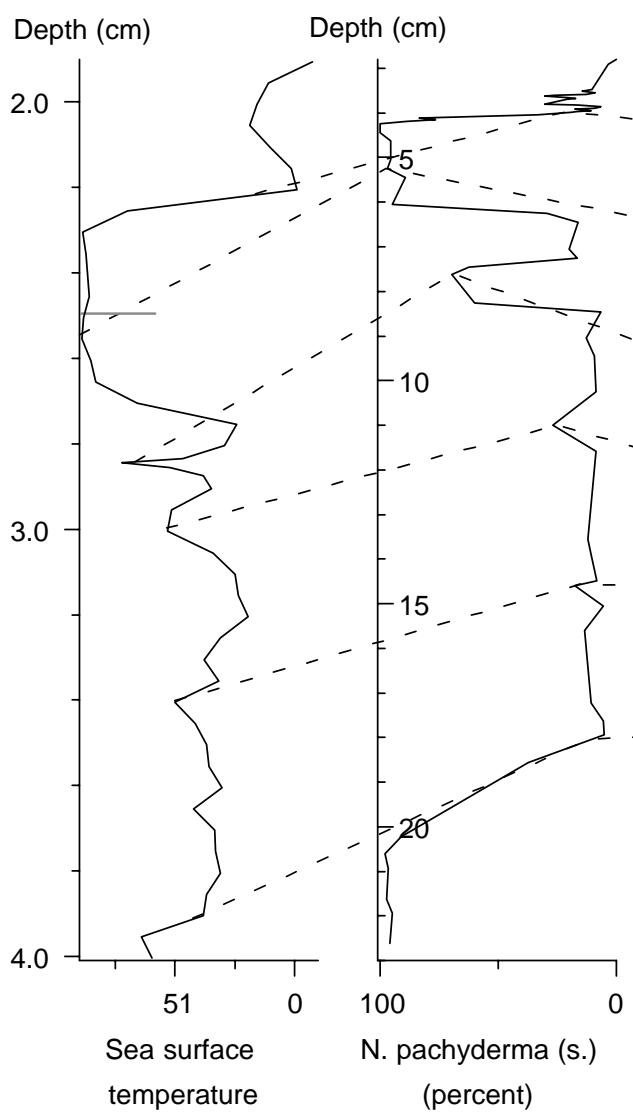

GRIP Ice yrBP
Troll 8903

Depth (cm)
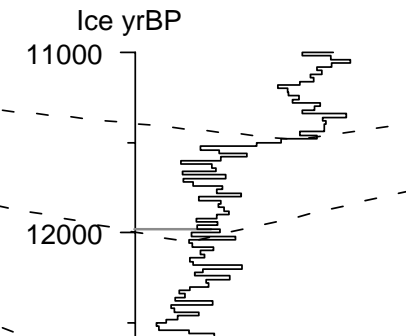

16000

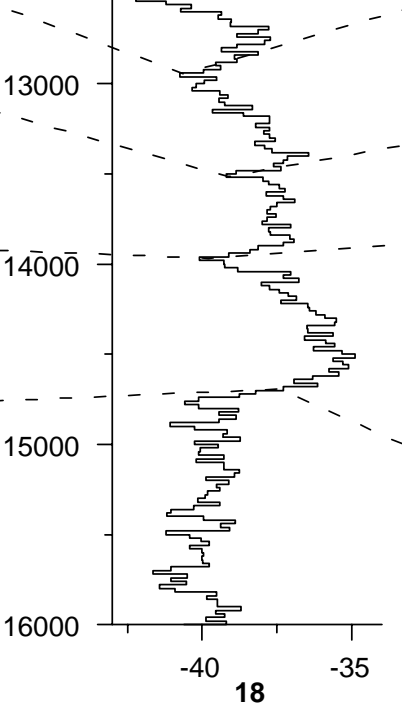

$\delta$ O

(per mil)
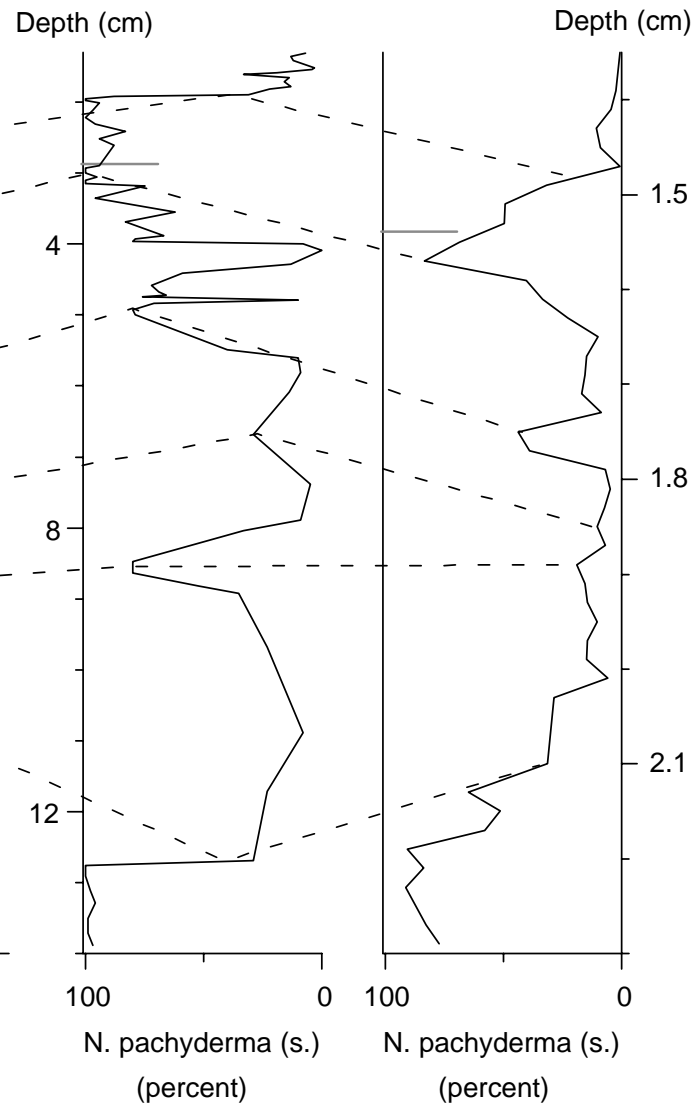

Fig. 2. The $\delta^{18} \mathrm{O}$ curve from the GRIP ice core (Johnsen et al., 1992) with its ice year based chronology (ss08c) correlated to the four marine proxy records with the aid of the event stratigraphy (Björck et al., 1998). Note that the Vedde Ash is indicated in four of the records by a grey bar.

Table 1

Estimated radiocarbon ages of the GRIP event stratigraphy (Johnsen et al., 1992; Björck, et al., 1998; Walker et al., 1999) and other defined events

GRIP events, event boundaries $\quad$ Estimated terrestrial ${ }^{14} \mathrm{C} \quad$ Geographic region and reference

and other defined events age (yr BP)

\begin{tabular}{|c|c|c|}
\hline Saksunarvatn Ash & 9000 & Faroe Islands (Mangerud et al., 1986), Norway (Gulliksen et al., 1998) \\
\hline GH-11.2 & $9800-9600$ & $\begin{array}{l}\text { SW Sweden (Björck et al., 1996), Holland (van Geel et al., 1989; Wagner et al., } \\
\text { 1999) }\end{array}$ \\
\hline Early Preboreal & $10,000-9800$ & SW Sweden (Björck et al., 1996), Switzerland (Ammann and Lotter, 1989) \\
\hline GS-1/Holocene & 10,000 & SW Sweden (Björck et al., 1996), Norway (Gulliksen et al., 1998) \\
\hline Vedde Ash & $10,300-10,350$ & W Norway (Mangerud et al., 1984), S Sweden (Wastegård et al., 1998) \\
\hline GI-1a/GS-1 & $10,800-10,600$ & S Sweden (Björck, 1984, 1996), Switzerland (Ammann and Lotter, 1989) \\
\hline GI-1b/GI-1a & $11,200-11,000$ & $\begin{array}{l}\text { Denmark (Andresen et al., 2000), Switzerland (Ammann and Lotter, 1989; } \\
\text { Lotter et al., 1992) }\end{array}$ \\
\hline GI-1c/GI-1b & 11,300 & $\begin{array}{l}\text { Denmark (Andresen et al., 2000), Switzerland (Ammann and Lotter, 1989; } \\
\text { Lotter et al., 1992) }\end{array}$ \\
\hline GI-1d/GI-1c & $11,900-12,000$ & $\begin{array}{l}\text { SE Sweden (Björck, 1984), Switzerland (Welten, 1982; Ammann and Lotter, } \\
\text { 1989), Holland (van Geel et al., 1989) }\end{array}$ \\
\hline GI-1e/GI-1d & 12,100 & $\begin{array}{l}\text { SE Sweden (Björck, 1984), Switzerland (Welten, 1982; Ammann and Lotter, } \\
\text { 1989), Holland (van Geel et al., 1989) }\end{array}$ \\
\hline GS-2/GI-1e & $12,500-12,700$ & $\begin{array}{l}\text { Switzerland (Ammann and Lotter, 1989), Holland (van Geel et al., 1989), SW } \\
\text { Sweden (Hammarlund, 1999) }\end{array}$ \\
\hline
\end{tabular}

All dates are from lake sediments, peat or cover sand where either terrestrial macrofossils or aquatic mosses in softwater lakes have been dated.

atmospheric ${ }^{14} \mathrm{C}$ content, the radiocarbon time scale is distorted, such that long periods in calendar time have almost constant radiocarbon ages, the so-called ${ }^{14} \mathrm{C}$ plateaus, while some short periods are characterized by abruptly decreasing ${ }^{14} \mathrm{C}$ age. During periods with more or less constant atmospheric ${ }^{14} \mathrm{C}$ content, radiocarbon 
age steadily decreases. Where an event boundary coincides with a ${ }^{14} \mathrm{C}$ plateau, it has a well-defined radiocarbon age. We can confidentially define radiocarbon ages for such boundaries, or for short distinct events, e.g. the Vedde Ash, within an uncertainty range of $\pm 100{ }^{14} \mathrm{C}$ yr (Table 2). For example, the PleistoceneHolocene boundary, which corresponds to the GS-1/ Holocene boundary in the GRIP scheme, falls within the 700 cal. yr long plateau of near-constant ${ }^{14} \mathrm{C}$ ages of $10,100-9900{ }^{14} \mathrm{C}$ yr BP (Stuiver et al., 1998) and is thus assigned an age of $10,000{ }^{14} \mathrm{C}$ yr BP. On the other hand, where an event boundary coincides with a period of rapidly decreasing ${ }^{14} \mathrm{C}$ ages, the radiocarbon age becomes less well defined. For radiocarbon ages around such periods we assume uncertainties of ca $\pm 150-200$ ${ }^{14} \mathrm{C}$ yr. The same uncertainty is estimated for ${ }^{\overline{14}} \mathrm{C}$ ages of horizons that fall between event boundaries, while uncertainties of $\pm 200-300{ }^{14} \mathrm{C}$ yr are assumed for ${ }^{14} \mathrm{C}$ ages that are regarded older or younger than the GI-1 and GS-1 events. The estimation of the calendar year (GRIP ice year) age, and its uncertainty, for each marine ${ }^{14} \mathrm{C}$ dated level is based on stratigraphic interpolations with the assumption of constant accumulation rate between each event boundary. For ${ }^{14} \mathrm{C}$ dated levels around boundaries or in the middle of short events we have estimated GRIP ice chronology uncertainties to vary between \pm 50 and $100 \mathrm{yr}$, while uncertainties for the remaining levels are estimated to $\pm 100-200 \mathrm{yr}$. Finally, as each marine ${ }^{14} \mathrm{C}$ dated level was assigned an ice-layer age and a terrestrial ${ }^{14} \mathrm{C}$ age, the latter could then be calibrated by using INTCAL98 (Stuiver et al., 1998). This exercise results in that only one of the estimated GRIP ages (including the uncertainty error) falls slightly outside the calibrated age range (Table 2). This may be a further indication that there are no significant time lags between GRIP and the terrestrial records.

\section{Results and discussion}

The estimated reservoir ages (Fig. 3) are calculated as the difference between each ${ }^{14} \mathrm{C}$ age obtained from the marine cores and the corresponding ${ }^{14} \mathrm{C}$ age estimate for the same event stratigraphic level in the terrestrial records. Our comparison shows that the ${ }^{14} \mathrm{C}$ ages in the North Atlantic core V23-81 display an enormous variation (Fig. 3); the calculated magnitude of reservoir ages varies between $+1300{ }^{14} \mathrm{C}$ yr and $-1100{ }^{14} \mathrm{C} \mathrm{yr}$, with a mean of $346 \mathrm{yr}$ and a weighted mean of $404 \mathrm{yr}$. The spread of ages within $1 \sigma$ is $\pm 538{ }^{14} \mathrm{C} \mathrm{yr}$, a degree of variation that renders this data-set unsuitable for estimating likely marine reservoir off-sets. With the exception of expected reservoir age values in the Holocene, no clear temporal trend can be distinguished. Furthermore, ca $25 \%$ of the dates are clearly too young, though the ${ }^{14} \mathrm{C}$ dates for samples of $N$. pachyderma (s) seem less prone to this problem, which suggests the influence of a bioturbation bias on the other dated samples consisting of planktonic foraminifera.

However, the three cores from the Norwegian Sea with their $25{ }^{14} \mathrm{C}$ dates (Table 1), show much less age variation for the study period (Fig. 3). The magnitude for the reservoir ages in the Norwegian Sea (RANS) varies between 400 and $1300{ }^{14} \mathrm{C}$ yr, but $60 \%$ of the age estimates suggest a RANS exceeding $1000{ }^{14} \mathrm{C}$ yr. The mean RANS is $1035{ }^{14} \mathrm{C}$ yr, while the weighted mean is $1043 \mathrm{yr}$, and the ages have a $1 \sigma$ spread of $\pm 252{ }^{14} \mathrm{C} \mathrm{yr}$. Furthermore, the data do not show any obvious decreasing or increasing trend (Fig. 3) throughout the $4000 \mathrm{cal}$. yr long period. This is inconsistent with the assumption that the North Atlantic, including the Iceland and Norwegian Sea, experienced a doubling of the marine reservoir effect during the GS-1, as a consequence of reduced advection of surface waters and increased abundance of sea ice (Bard et al., 1994; Bondevik et al., 1999). The occurrence of the Vedde Ash in three of the marine cores, and dated to ca $10,350{ }^{14} \mathrm{C}$ yr BP (Mangerud et al., 1984; Wastegård et al., 1998) in the middle of GS-1, gives us an additional opportunity to compare marine and terrestrial ${ }^{14} \mathrm{C}$ dates; the five ${ }^{14} \mathrm{C}$ dates situated at, slightly above or slightly below, the Vedde Ash in these cores give a mean ${ }^{14} \mathrm{C}$ age of $11,360 \mathrm{yr}$ $\mathrm{BP}$, which is consistent with a RANS of ca $1000{ }^{14} \mathrm{C}$ yr.

There is, however, a quasi-cyclic pattern in the Norwegian Sea data, and fitting a polynomial function suggests two maxima in RANS at 12,300 and 13,600 cal. $\mathrm{yr} \mathrm{BP}$, and three minima at 11,500, 13,000 and 14,500 cal. yr BP. Such fluctuations do not necessarily indicate changes in ocean ventilation, but could reflect delayed responses to variations in atmospheric ${ }^{14} \mathrm{C}$ content, which will be damped by the vertical diffusive exchange, but still show up in the marine ${ }^{14} \mathrm{C}$ record. Because of this effect, it can be calculated from published data (Stuiver et al., 1998), for example, that the tropical ocean reservoir age fluctuated between 300 and $800{ }^{14} \mathrm{C}$ yr during the early Holocene, a period of significant $\Delta{ }^{14} \mathrm{C}$ changes.

\section{Conclusions}

The comparisons outlined above show that RANS was much higher than is usually assumed during the period 15,000-11,000 cal. yr BP. This conclusion poses serious questions about how marine ${ }^{14} \mathrm{C}$ chronologies have been used to construct regional chronologies. Since there is a fairly high consistency in the results, indicating that relative ${ }^{14} \mathrm{C}$ ages in this marine realm may be reliable, we suggest a RANS of ca $1000 \mathrm{yr}( \pm 250 \mathrm{yr})$ for this period. The real degree of uncertainty is, difficult to quantify because of many different uncertainties. The Norwegian Sea data indicate that RANS varied during 
Table 2

Uncorrected ${ }^{14} \mathrm{C}$ dates from the four marine cores in Fig. $2^{\mathrm{a}}$ with dated foraminiferal species ${ }^{\mathrm{b}}$, estimated corresponding age in the GRIP ice core (ss08c) with our error estimates, the assumed terrestrial ${ }^{14} \mathrm{C}$ age of the corresponding event stratigraphic level with our error estimates, and the calibrated age (Stuiver et al., 1998) of the assumed terrestrial ${ }^{14} \mathrm{C}$ age. Empty space means the same value as above

\begin{tabular}{|c|c|c|c|c|c|c|c|c|}
\hline Core $^{a}$ & Depth $(\mathrm{cm})$ & ${ }^{14} \mathrm{C}$ age, yr BP & ${ }^{14} \mathrm{C}$ dated species ${ }^{\mathrm{b}}$ & GRIP age & Err. $( \pm)$ & Terrestrial ${ }^{14} \mathrm{C}$ age & Err. $( \pm)$ & Calibrated age, yr BP \\
\hline \multirow[t]{10}{*}{ HM } & 195 & $10,885 \pm 135$ & N. p. (s) & 11,250 & 50 & 9700 & 150 & $10,750-11,230$ \\
\hline & 250 & $11,675 \pm 180$ & N. p. (s) & 11,980 & 20 & 10,350 & 100 & $11,750-12,650$ \\
\hline & 270 & $11,635 \pm 160$ & N. p. (s) & 12,600 & 100 & 10,700 & 150 & $12,350-13,000$ \\
\hline & 284.5 & $11,66 \overline{5} \pm 80$ & N.p. (s) & 13,000 & 75 & 11,250 & 100 & $13,040-13,420$ \\
\hline & 289.5 & $12,080 \pm 85$ & N. p. (s) & 13,200 & 100 & 11,400 & 150 & $13,150-13,800$ \\
\hline & 305 & $12,765 \pm 195$ & N. p. (s) & 13,500 & 100 & 11,500 & 150 & $13,150-13,800$ \\
\hline & 335 & $12,820 \pm 105$ & N. p. (s) & 13,900 & 100 & 11,800 & 150 & $13,450-14,100$ \\
\hline & 365.5 & $12,995 \pm 135$ & N. p. (s) & 14,300 & 150 & 12,300 & 150 & $14,050-15,150$ \\
\hline & 390 & $13,605 \pm 130$ & N. p. (s) & 14,700 & 100 & 12,700 & 150 & $14,350-15,650$ \\
\hline & 430 & $14,540 \pm 155$ & N. p. (s) & 15,000 & 150 & 13,000 & 300 & $14,350-16,150$ \\
\hline \multirow[t]{6}{*}{ T3.1 } & 407 & $10,950 \pm 115$ & N.1. & 11,500 & 50 & 10,000 & 100 & $11,230-11,690$ \\
\hline & 545 & $11,600 \pm 120$ & N.1. & 12,300 & 100 & 10,400 & 100 & $11,950-12,650$ \\
\hline & 825 & $12,170 \pm 170$ & N.1. & 13,100 & 75 & 11,250 & 100 & $13,040-13,420$ \\
\hline & 1158 & $12,850 \pm 150$ & N.1. & 13,700 & 100 & 11,600 & 200 & $13,200-13,850$ \\
\hline & 1454 & $13,025 \pm 150$ & N.1. & 14,000 & 100 & 12,000 & 100 & $13,650-14,300$ \\
\hline & 2060 & $13,885 \pm 155$ & N.1. & 14,800 & 150 & 12,800 & 150 & $14,350-15,750$ \\
\hline \multirow[t]{9}{*}{$\mathrm{T} 8$} & 177 & $10,835 \pm 115$ & Y. lent. & 11,400 & 75 & 10,000 & 100 & $11,230-11,690$ \\
\hline & 266 & $11,100 \pm 110$ & N.1. & 11,980 & 20 & 10,300 & 100 & $11,750-12,600$ \\
\hline & 276 & $11,595 \pm 90$ & N.1. & 12,050 & 75 & 10,300 & 150 & $11,650-12,650$ \\
\hline & 320 & $11,665 \pm 75$ & E. exc. & 12,300 & 100 & 10,400 & 150 & $11,950-12,800$ \\
\hline & 390 & $11,785 \pm 130$ & N.1. Cr & 12,500 & 75 & 10,600 & 150 & $12,300-12,900$ \\
\hline & 460 & $12,305 \pm 125$ & N.1. & 12,950 & 100 & 11,200 & 150 & $13,010-13,390$ \\
\hline & 510 & $12,480 \pm 145$ & N.l. & 13,050 & 50 & 11,300 & 100 & $13,150-13,420$ \\
\hline & 1090 & $13,390 \pm 85$ & Y. lent. & 14,400 & 100 & 12,300 & 200 & $14,050-15,250$ \\
\hline & 1290 & $13,530 \pm 75$ & E. exc. & 14,800 & 150 & 12,800 & 200 & $14,350-15,850$ \\
\hline \multirow[t]{33}{*}{ V } & $135-136$ & $9490 \pm 200$ & G. infl. & 10,350 & 200 & 9200 & 200 & $10,150-10,700$ \\
\hline & & $9890 \pm 160$ & G. bull. & & & & & \\
\hline & & $9610 \pm 150$ & G. glut. & & & & & \\
\hline & $141-143$ & $10,940 \pm 150$ & N. p. (s) & 11,200 & 75 & 9600 & 150 & $10,740-11,170$ \\
\hline & $143-144$ & $10,120 \pm 180$ & N. p. (s) & 11,300 & 50 & 9700 & 150 & $10,750-11,230$ \\
\hline & & $10,450 \pm 200$ & G. infl. & & & & & \\
\hline & $146-147$ & $9600 \pm 210$ & G. glut. & 11,400 & 75 & 9900 & 100 & $11,180-11,560$ \\
\hline & $147-148$ & $10,260 \pm 190$ & G. infl. & 11,500 & 50 & 10,000 & 100 & $11,230-11,690$ \\
\hline & $150-151$ & $11,110 \pm 140$ & N.p. (s) & 11,600 & 50 & 10,000 & 100 & $11,230-11,690$ \\
\hline & $154-155$ & $10,800 \pm 170$ & N. p. (s) & 11,800 & 150 & 10,200 & 200 & $11,350-12,350$ \\
\hline & $157-158$ & $11,280 \pm 90$ & N. p. (s) & 12,100 & 100 & 10,400 & 100 & $11,950-12,650$ \\
\hline & & $11,470 \pm 140$ & N. p. (s) & & & & & \\
\hline & $160-161$ & $11,380 \pm 150$ & N. p. (s) & 12,600 & 100 & 10,700 & 150 & $12,350-13,000$ \\
\hline & $164-165$ & $11,500 \pm 200$ & G. infl. & 12,700 & 100 & 10,900 & 100 & $12,840-13,130$ \\
\hline & & $11,500 \pm 210$ & G. bull. & & & & & $12,880-13,160$ \\
\hline & $171-172$ & $10,530 \pm 160$ & G. infl. & 12,800 & 100 & 11,000 & 150 & \\
\hline & & $11,170 \pm 180$ & G. bull. & & & & & \\
\hline & $172-173$ & $11,980 \pm 110$ & N.p. (s) & 12,850 & 100 & 11,000 & 150 & $12,880-13,160$ \\
\hline & & $10,960 \pm 200$ & G. infl. & & & & & \\
\hline & & $11,860 \pm 170$ & G. bull. & & & & & \\
\hline & & $11,140 \pm 190$ & G. glut. & & & & & \\
\hline & $175-176$ & $10,990 \pm 190$ & N. p. (s) & 12,950 & 100 & 11,100 & 100 & $12,950-13,180$ \\
\hline & & $10,780 \pm 190$ & N. p. (s) & & & & & \\
\hline & $180-181$ & $12,240 \pm 220$ & G. infl. & 13,200 & 100 & 11,350 & 100 & $13,170-13,430$ \\
\hline & & $11,990 \pm 280$ & G. bull. & & & & & \\
\hline & $186-187$ & $10,500 \pm 230$ & G. infl. & 13,500 & 150 & 11,600 & 150 & $13,390-13,830$ \\
\hline & & $11,540 \pm 210$ & G. bull. & & & & & \\
\hline & $188-190$ & $11,850 \pm 200$ & N.p. (s) & 13,950 & 75 & 12,000 & 100 & $13,650-14,300$ \\
\hline & & $11,330 \pm 230$ & G. infl. & & & & & \\
\hline & & $11,650 \pm 210$ & G. bull. & & & & & \\
\hline & $194-195$ & $12,660 \pm 240$ & N. p. (s) & 14,200 & 100 & 12,200 & 150 & $13,750-15,150$ \\
\hline & & $11,940 \pm 210$ & G. infl. & & & & & \\
\hline & & $12,840 \pm 230$ & G. bull. & & & & & \\
\hline
\end{tabular}


Table 2 (continued)

\begin{tabular}{lllllllll}
\hline Core $^{\mathrm{a}}$ & Depth $(\mathrm{cm})$ & ${ }^{14} \mathrm{C}$ age, yr BP & ${ }^{14}$ C dated species ${ }^{\mathrm{b}}$ & GRIP age & Err. $( \pm)$ & Terrestrial ${ }^{14}$ C age & Err. $( \pm)$ & Calibrated age, yr BP \\
\hline & $198-199$ & $12,720 \pm 220$ & N. p. (s) & 14,400 & 150 & 12,400 & 200 & $14,100-15,050$ \\
& $12,530 \pm 220$ & G. infl. & & & & & \\
& $12,910 \pm 240$ & G. bull. & & & & 200 & $14,350-15,950$ \\
\hline
\end{tabular}

${ }^{\mathrm{a}} \mathrm{HM}=\mathrm{HM} 79-6 / 4, \mathrm{~T} 3.1=$ Troll 3.1, T8 $=$ Troll 8903, V = V23-81.

${ }^{\mathrm{b}} \mathrm{N}$. p. $(\mathrm{s})=$ Neogloboquadrina pachyderma $($ sinistral), G. infl.=Globorotalia inflata, G. bull. =Globigerina bulloides, G. glut. $=$ Globigerinita glutinata, Y. lent. $=$ Yoldiella lenticula, $\mathrm{N} .1 .=$ Nonionellina labradorica,, $\mathrm{E}$. exc. $=$ Elphidium excavatum, $\mathrm{Cr}=$ Cassidulina reniforme.

All ages refer to AD 1950.

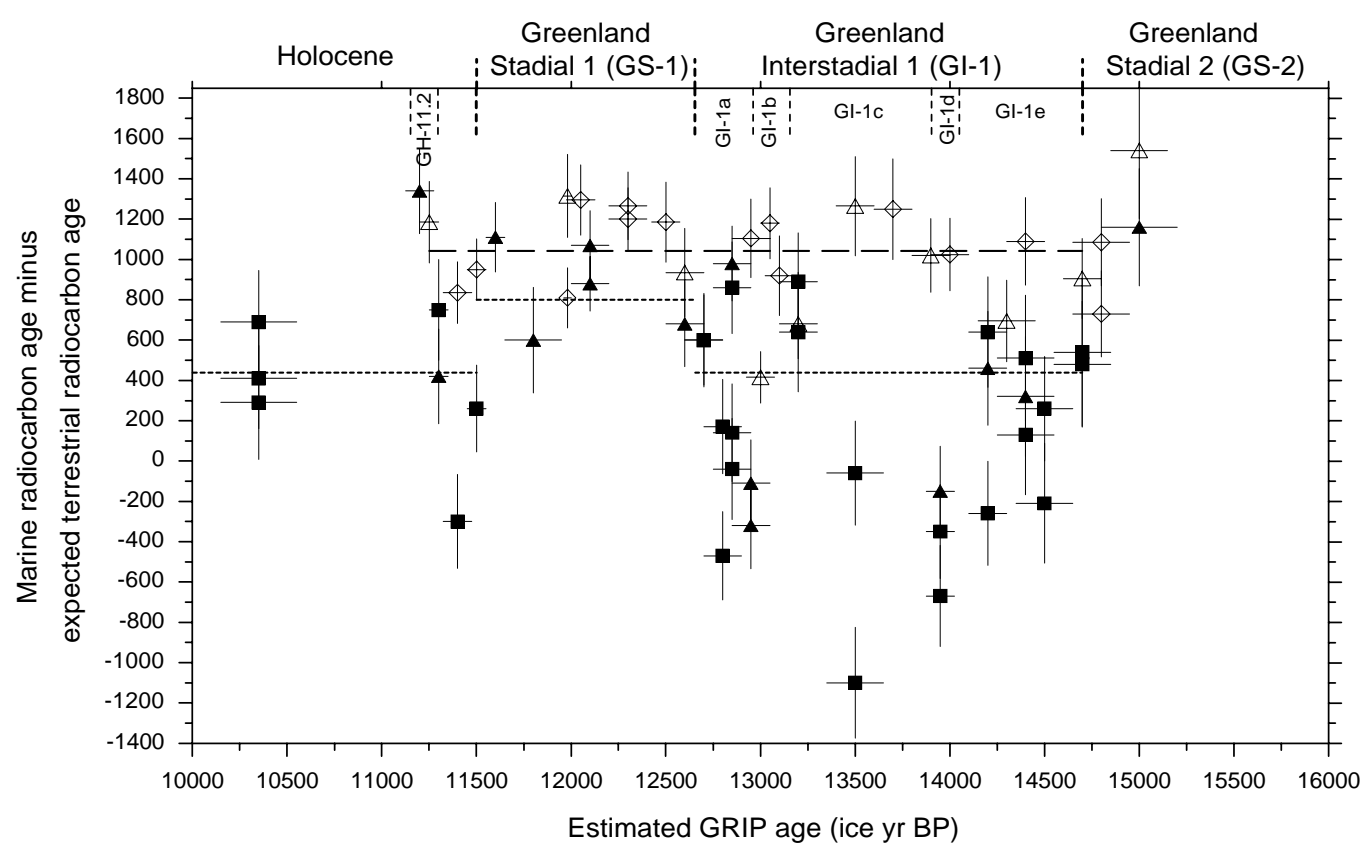

Fig. 3. The difference between the marine ${ }^{14} \mathrm{C}$ ages and estimated terrestrial ${ }^{14} \mathrm{C}$ ages, i.e. the marine reservoir age, related to the inferred GRIP age (ss08c). Reservoir ages for North Atlantic dates (filled symbols), Norwegian Sea dates (open symbols), dates on benthic foraminifera (diamonds), dates on Neogloboquadrina pachyderma (sinistral) foraminifera (triangles), and dates on other planktonic foraminifera (squares) are shown with different symbols. The weighted mean of our Norwegian Sea reservoir age is shown as a broken line, while the commonly used reservoir age of 440 yr before and after Younger Dryas, and the Younger Dryas reservoir age of ca $800 \mathrm{yr}$ (Bard et al., 1994), is shown as a dotted line. The upper $x$-axis shows the chronologic position of the events and episodes in the GRIP ice core (Björck et al., 1998) according to the ss08c time-scale.

the Last Deglaciation, which suggests changing atmospheric ${ }^{14} \mathrm{C}$ concentrations rather than changes in ocean ventilation. This conclusion is also supported by reconstructions of the limit of sea-ice throughout the Last Deglaciation (Koc et al., 1993), which suggest that the whole period was characterized by only a small icefree corridor along the Norwegian coast. Under such a scenario, a fairly stable mode in thermohaline circulation, and hence quasi-constant marine reservoir ages, would be expected.

\section{Acknowledgements}

We wish to thank John Lowe, London, for many good review comments and corrections of the linguistic style.

\section{References}

Ammann, B., Lotter, A.F., 1989. Late-glacial radiocarbon- and palynostratigraphy on the Swiss Plateau. Boreas 18, 109-126.

Andresen, C.S., Björck, S., Bennike, O., Heinemeier, J., Kromer, B., 2000. What do $\delta^{14} \mathrm{C}$ changes across the Gerzensee oscillation/GI-1b event imply for deglacial oscillations? Journal of Quaternary Science 15, 203-214.

Austin, W.E.N., Bard, E., Hunt, J.B., Kroon, D., Peacock, J., 1995. The 14C age of the Icelandic Vedde Ash: implications for Younger Dryas marine reservoir age corrections. Radiocarbon 37 , $53-62$.

Bard, E., Arnold, M., Mangerud, J., Paterne, M., Labeyrie, L., Duprat, J., Mélières, M.-A., Sønstegaard, E., Duplessy, J.-C., 1994. The North Atlantic atmosphere-sea surface ${ }^{14} \mathrm{C}$ gradient during the Younger Dryas climatic event. Earth and Planetary Science Letters 126, 275-287.

Björck, S., 1984. Bio- and chronostratigraphic significance of the older Dryas chronozone - on the basis of new radiocarbon dates. Geologiska Föreningen i Stockholm Förhandlingar 106, 81-91. 
Björck, S., Kromer, B., Johnsen, S., Bennike, O., Hammarlund, D., Lemdahl, G., Possnert, G., Rasmussen, T.L., Wohlfarth, B., Hammer, C.U., Spurk, M., 1996. Synchronised terrestrial-atmospheric deglacial records around the North Atlantic. Science 274, $1155-1160$

Björck, S., Walker, M.J.C., Cwynar, L.C., Johnsen, S., Knudsen, K.L., Lowe, J.J., Wohlfarth, B., 1998. An event stratigraphy for the last termination in the North Atlantic region based on the Greenland ice-core record: a proposal by the INTIMATE group. Journal of Quaternary Science 13 (4), 283-292.

Bond, G.C., Broecker, W.S., Johnsen, S., McManus, J., Labeyrie, L., Jouzel, J., Bonani, G., 1993. Correlations between climate records from North Atlantic sediments and Greenland ice. Nature 365, 143-147.

Bond, G.C., Mandeville, C., Hoffmann, S., 2001. Were rhyolithic glasses in the Vedde Ash and in the North Atlantic's Ash Zone 1 produced by the same volcanic eruption? Quaternary Science Reviews 20, 1189-1200.

Bondevik, S., Birks, H.H., Gulliksen, S., Mangerud, M., 1999. Late Weichselian marine ${ }^{14} \mathrm{C}$ reservoir ages at the western coast of Norway. Quaternary Research 52, 104-114.

Broecker, W.S., Andree, M., Wolfli, W., Oeschger, H., Bonani, G., Kennett, J., Peteet, D., 1988. The chronology of the last deglaciation: implications to the cause of the Younger Dryas event. Paleoceanography 3 (1), 1-19.

van Geel, B., Coope, G.R., van der Hammen, T., 1989. Palaeoecology and stratigraphy of the Lateglacial type section at Usselo (The Netherlands). Review of Palaeobotany and Palynology 60, 25-129.

Gulliksen, S., Birks, H.H., Possnert, G., Mangerud, J., 1998. A calendar age estimate of the Younger Dryas-Holocene boundary at Kråkenes, western Norway. The Holocene 8 (3), 249-259.

Haflidason, H., Sejrup, H.P., Klitgaard Kristensen, D., Johnsen, S., 1995. Coupled response of the late glacial climatic shifts of northwest Europe reflected in Greenland ice cores: evidence from the northern North Sea. Geology 23 (12), 1059-1062.

Hammarlund, D., 1999. Ostracod stable isotope records from a deglacial isolation sequence in southern Sweden. Boreas 29, 564-574.

Hughen, K.A., Overpeck, J.T., Lehman, S.J., Kashgarian, M., Southon, J., Peterson, L.C., Alley, R., Sigman, D.M., 1998. Deglacial changes in ocean circulation from an extended radiocarbon calibration. Nature 391, 65-68.

Jansen, E., Veum, T., 1990. Evidence for two-step deglaciation and its impact on North Atlantic deep-water circulation. Nature 343, 612-616.

Johnsen, S.J., Clausen, H.B., Dansgaard, W., Fuhrer, K., Gundestrup, N., Hammer, C.U., Iversen, P., Jouzel, J., Stauffer, B., Steffensen,
J.P., 1992. Irregular glacial interstadials recorded in a new Greenland ice core. Nature 359, 311-313.

Kennett, J.P., Ingram, B.L., 1995. A 20,000-year record of ocean circulation and climate change from the Santa Barbara basin. Nature 377, 510-514.

Koç Karpuz, N., Jansen, E., 1992. A high-resolution diatom record of the last deglaciation from the SE Norwegian Sea: documentation of rapid climate changes. Paleoceanography 7 (4), 499-520.

Koç, N., Jansen, E., Haflidason, H., 1993. Paleoceanographic reconstructions of surface ocean conditions in the Greenland, Iceland and Norwegian seas during the last $14 \mathrm{ka}$ based on diatoms. Quaternary Science Reviews 12, 115-140.

Lehman, S.J., Jones, G.A., Keigwin, L.G., Andersen, E.S., Butenko, G., Ostmo, S.-R., 1991. Initiation of Fennoscandian ice-sheet retreat during the last deglaciation. Nature 349, 513-516.

Lehman, S.J., Keigwin, L.D., 1992. Sudden changes in North Atlantic circulation during the last deglaciation. Nature 356, 757-762.

Lotter, A.F., Eicher, U., Siegenthaler, U., Birks, H.J.B., 1992. Lateglacial climatic oscillations as recorded in Swiss lake sediments. Journal of Quaternary Science 7, 187-204.

Mangerud, J., Furnes, H., Johansen, J., 1986. A 9000-year-old ash bed on the Faroe islands. Quaternary Research 26, 262-265.

Mangerud, J., Lie, S., Furnes, H., Kristiansen, I.L., Lömo, L., 1984. A Younger Dryas Ash bed in western Norway and its possible correlations with tephra in cores from the Norwegian Sea and the North Atlantic. Quaternary Research 21, 85-104.

Stuiver, M., Reimer, P.J., Bard, E., Beck, J.W., Burr, G.S., Hughen, K.A., Kromer, B., McCormac, G., van der Plicht, J., Spurk, M., 1998. INTCAL98 radiocarbon age calibration, 24,000-0 cal. BP. Radiocarbon 40 (3), 1041-1083.

Waelbroeck, C., Duplessy, J.-C., Michel, E., Labeyrie, L., Paillard, D., Duprat, J., 2001. The timing of the last deglaciation in North Atlantic climate records. Nature 412, 724-727.

Wagner, F., Bohncke, S.J.P., Dilcher, D.L., Kuerschner, W.M., van Geel, B., Visscher, H., 1999. Century-scale shifts in early Holocene atmospheric $\mathrm{CO}_{2}$ concentration. Science 284, 1971-1973.

Walker, M.J.C., Björck, S., Lowe, J.J., Cwynar, L.C., Johnsen, S., Knudsen, K.-L., Wohlfarth, B., the INTIMATE Group, 1999. Isotopic events' in the GRIP ice core: a stratotype for the Late Pleistocene. Quaternary Science Reviews 18, 1143-1150.

Wastegård, S., Björck, S., Possnert, G., Wohlfarth, B., 1998. Evidence for the occurrence of Vedde Ash in Sweden: radiocarbon and calendar age estimates. Journal of Quaternary Science 13 (3), 271-274.

Welten, M., 1982. Vegetationsgeschichtlige Untersuchungen in den westlichen Schweizer Alpen: Bern-Wallis. Birkhäuser, Basel. 